\title{
Deoxygenation of Chinese long-flame coal in low-temperature pyrolysis
}

\author{
Zibing Wang ${ }^{1}$ Chao Wang ${ }^{2} \cdot$ Running Kang ${ }^{1,3} \cdot$ Feng Bin $^{3} \cdot$ Xiaolin Wei $^{3,4}$
}

Received: 16 June 2017 / Accepted: 28 September 2017/Published online: 23 October 2017

(C) Akadémiai Kiadó, Budapest, Hungary 2017

\begin{abstract}
Long-flame coal is a typical low-ranked coal that is not fully utilized and has a huge global reserve. Highcontent oxygen is a significant negative factor for low-rank coal utilization. The TG-FTIR-GC/MS method was applied to investigate the migration behavior of oxygen and the variation in the properties of Chinese long-flame coal during low-temperature pyrolysis. It was found that the oxygen migration ratios in long-flame coal toward gas and tar were 47.7 and $5.2 \%$, respectively, at $550{ }^{\circ} \mathrm{C}$, that the initial oxygen migration temperatures of hydroxyl, carboxyl, carbonyl and ether bonds were 500, 200, 300 and $350{ }^{\circ} \mathrm{C}$, respectively, that the decomposition rates were $8.2,90,99.2$ and $86 \%$ at $550{ }^{\circ} \mathrm{C}$, respectively, that the oxygen in gas existed mainly in the form of $\mathrm{CO}_{2}$ and $\mathrm{CO}$, and that the oxygen in tar existed mainly in the form of phenolic compounds. The further removal of oxygen was due to the decomposition of hydroxyl and a small amount of stable ether bonds. Furthermore, deoxygenation suggested that the decrease in oxygen had a positive effect on
\end{abstract}

Xiaolin Wei

xlwei@imech.ac.cn

1 College of Metallurgy and Energy, North China University of Science and Technology, Tangshan 063210, Hebei, People's Republic of China

2 School of Energy, Power and Mechanical Engineering, North China Electric Power University, Beijing 102206, People's Republic of China

3 State Key Laboratory of High Temperature Gas Dynamics, Institute of Mechanics, Chinese Academy of Sciences, Beijing 100190, People's Republic of China

4 School of Engineering Science, University of Chinese Academy of Sciences, Beijing 100049, People's Republic of China coal liquefaction and resulted in a decrease in its hydrophilicity.

Keywords Coal · Low-temperature pyrolysis · Oxygen migration $\cdot$ Deoxygenation

\section{Introduction}

Low-rank coal reserves make up approximately $50 \%$ of the total reserves of coal in the world [1], but the utilization of low-rank coal is inefficient due to its high water content, high-oxygen content, low heat value and low economic value. However, low-rank coal is a significant resource of both energy and chemicals, so it is of great importance to convert it into more valuable products. Currently, longflame coal is a significant coal resource and might play an important role in the future in China, although it holds the lowest coal rank in bituminous coal, rank $\mathrm{D}$, which is slightly higher than lignite.

Up until the present, many methods of upgrading lowrank coal have been studied, such as preliminary upgrading with drying and cleaning [2], pyrolyzation for semi-coke and tar, gasification for combustible gas and chemical feedstock, liquefaction for tar or chemical feedstock as well as combustion in different ways for heat [3]. Aside from preliminary upgrading, the gasification, liquefaction and pyrolyzation play important roles in the cleaning and utilization of low-rank coal. Because of the excellent safety, controllability and product diversity of low-temperature pyrolysis, it has become one of the most economical low-rank coal upgrading methods [4-10].

While upgrading low-ranked coal, a number of studies have been conducted to explore the fate of chemical structures, sash, water, S and N [11-13]. For example, 
Solomon et al. [14] built a prediction model of coal pyrolysis according to ${ }^{13} \mathrm{C}$-NMR. Xin et al. [15] reported the relationship between coal structure and its pyrolysis product distribution based on FTIR. Lievens et al. [16] also studied the light volatile fraction of low-rank coal via pyGC/MS.

Up until the present, the investigations on long-flame coal were mostly focused on its pyrolysis product distribution, gas adsorption, diffusion dynamics and macromolecular structure characteristics [17-20]. In coal pyrolysis, when compared to de-ashing and drying, deoxygenation is more important to further improve the coal's net calorific value, hydrophobicity, chemical reactivity due to oxygen causing $\mathrm{C}$ bondage, and $\mathrm{H}$ bondage, and it reduce the hydrophobicity of the coal [21]. This process results in the oxygen-containing functional groups with carbon and hydrogen affecting the reactivity of lowrank coal. Oxygen migrates to pyrolysis products in various forms at different pyrolysis temperatures, [22], including hydroxyl $(-\mathrm{OH})$, carboxyl $(-\mathrm{COOH})$, carbonyl $(-\mathrm{C}=\mathrm{O})$, ether bond $(\mathrm{C}-\mathrm{O}-\mathrm{C})$ and oxygen-containing heterocycle. For example, Zhao and Shi [23] used the mass ratio of oxygen in $\mathrm{CO}_{x}$ and the total oxygen mass of raw coal as the indicator to find the optimal catalyst-free deoxygenation temperature was $400{ }^{\circ} \mathrm{C}$ under $1 \mathrm{MPa}$ of hydrogen. Mráziková et al. [24] reported that the oxygen-containing heterocycle could be ignored among the main oxygencontaining functional groups and that carbonyl was decomposed completely before $550{ }^{\circ} \mathrm{C}$. Liu et al. [17] reported that the migration ratio of oxygen to gas was up to $70 \%$ and the ratio to tar was $<10 \%$ when Shenfu coal was treated from room temperature to $900{ }^{\circ} \mathrm{C}$. Sharma et al. $[25,26]$ also found the linear relationship between $\mathrm{H} / \mathrm{C}$ or $\mathrm{O} / \mathrm{C}$ ratio and pyrolysis temperature, and the residual oxygen was mainly phenolic and stable at high temperature. Concerning its distinctly different properties from low-rank coal, an effective deoxidization method of Chinese long-flame coal during low-temperature pyrolysis might be difficult to obtain, and developing detailed oxygen migration pathways is urgent.

In this study, the change of oxygen-containing functional groups and pyrolysis volatiles, especially oxygencontaining gas, was analyzed using infrared transmission (IR), thermogravimetric analyzer (TG), Fourier transform infrared spectrometer (FTIR) and chromatograph (GC)/mass spectrometer (MS). Oxygen-containing functional groups analysis is necessary for the molecular calculation of oxygen to describe the action of oxygen during low-temperature pyrolysis. The migration of oxygen during the low-temperature pyrolysis of coal was investigated with the $\mathrm{O} / \mathrm{C} / \mathrm{H}$ ratio as an indicator of the oxygen migration extent. The effects of oxygen on semi-coke were discussed at the end.

\section{Experimental}

\section{Sample analysis}

The coal was ground to sizes of 80 meshes and dried at $40{ }^{\circ} \mathrm{C}$ in a vacuum for $2 \mathrm{~h}$. National Standards (China) GB/ T 212-2008 and GB/T 476-2001 were used in the analysis, and the results are shown in Table 1.

\section{Experimental system}

The pyrolysis experiment in a closed system was carried out in a TGA (PerkinElmer TGA Pyrir1) coupled with an online FTIR (FT-IR Vertex 70 FTIR spectrometer), a gas chromatograph (Clarus 680) and a mass spectrometer (Clarus SQ 8T), as shown in Fig. 1.

The TGA was done at a heating rate of $20{ }^{\circ} \mathrm{C} \mathrm{min}^{-1}$ from 25 to $600{ }^{\circ} \mathrm{C}$ in Ar to cause a slowing of the pyrolysis, making it possible to easily analyze the gas generated at different pyrolysis temperatures.

The oxygen-containing structures of pyrolysis volatiles, such as hydroxyl, alcohol, aldehyde, ketone and carboxylic acid, could be determined according to an infrared spectrogram from 400 to $4500 \mathrm{~cm}^{-1}$ of exhaust gaseous form TGA on NICOLET iS10 with a DTGS detector.

Synchronized GC-MS was used to determine the composition of volatiles generated at 350,450 and $550{ }^{\circ} \mathrm{C}$, and the spectrogram of total ion current (TIC).

Under the same conditions, the structural changes of oxygen-containing functional groups in the semi-coke, which were heated to 350,450 and $550{ }^{\circ} \mathrm{C}$ and cooled, were examined with an infrared transmission meter.

Table 1 Properties of coal

\begin{tabular}{|c|c|c|c|c|c|c|c|c|c|}
\hline \multicolumn{4}{|c|}{ Proximate analysis ad/mass $\%$} & \multicolumn{5}{|c|}{ Ultimate analysis ad $/$ mass $\%$} & \multirow[t]{2}{*}{$Q_{\text {net,ad }} / \mathrm{MJ} \mathrm{kg}^{-1}$} \\
\hline W & A & $\mathrm{V}_{\mathrm{daf}}$ & $\mathrm{FC}$ & $\mathrm{C}$ & $\mathrm{H}$ & $\mathrm{O}$ & $\mathrm{N}$ & $S$ & \\
\hline 11.55 & 15.06 & 37.53 & 45.70 & 56.28 & 4.92 & 11.02 & 0.82 & 0.35 & 20.85 \\
\hline
\end{tabular}

$\mathrm{W}, \mathrm{A}, \mathrm{V}$ and FC represent water, ash, volatiles and fixed carbon, respectively 


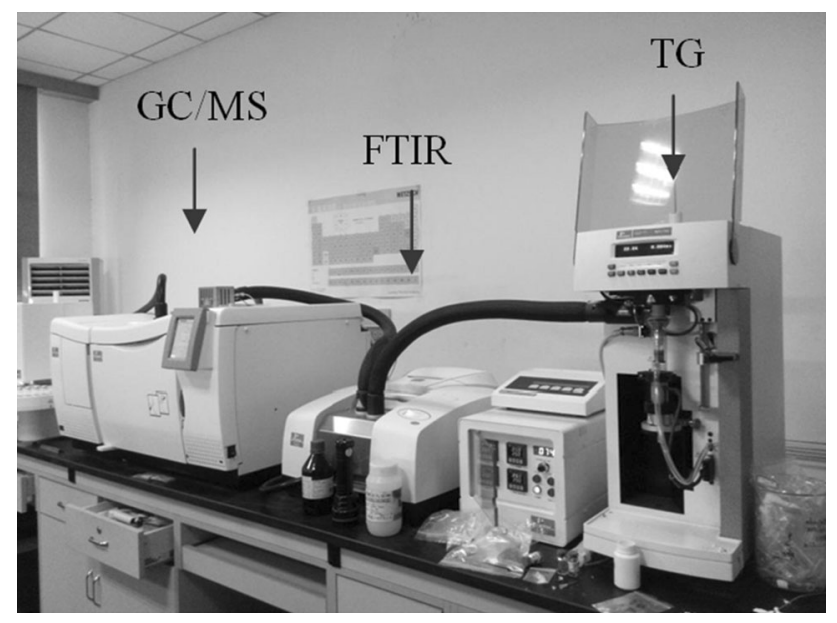

Fig. 1 Main experimental system

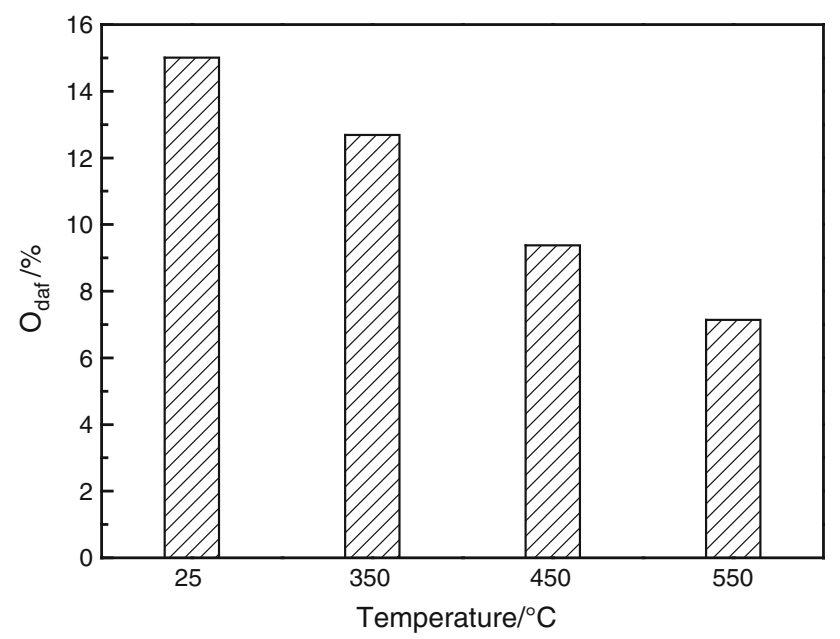

Fig. 2 Oxygen proportion in semi-cokes

\section{Results and discussion}

\section{Oxygen element in coal and semi-coke}

The migration ratio of oxygen element was defined as the following,

Migration rate $=\frac{\mathrm{O} \text { migrating in any form }}{\mathrm{O} \text { in raw coal }} \times 100 \%$

as shown in Table 1 and Fig. 2, and the oxygen content in raw coal $\left(25^{\circ} \mathrm{C}\right)$ was $15.01 \%\left(\mathrm{O}_{\mathrm{daf}}\right)$. The migration ratios of oxygen to volatiles were $15.5,37.5$ and $52.9 \%$ at 350 , 450 and $550{ }^{\circ} \mathrm{C}$, respectively.

\section{Oxygen-containing groups in coal and semi-coke}

The infrared transmission analysis of coal and semi-coke shown in Fig. 3 demonstrates that their oxygen-containing functional groups after pyrolysis at temperatures below

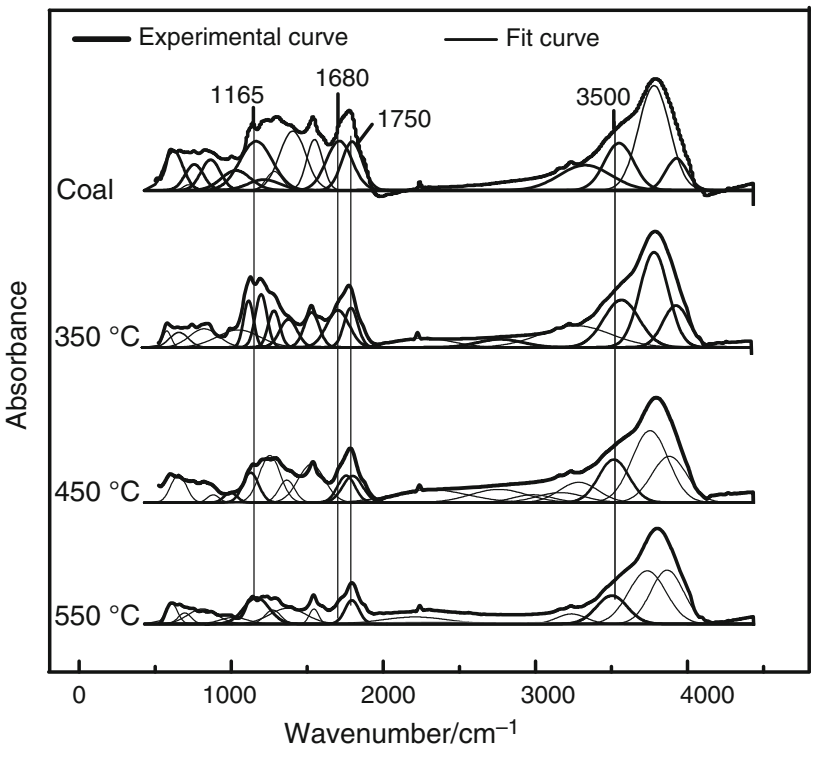

Fig. 3 Result of Gaussian sub-peak fitting

$550{ }^{\circ} \mathrm{C}$ were mainly the following: hydroxyl, carboxyl, carbonyl and ether bonds.

According to the qualitative and quantitative FTIR analysis of functional groups in coal [27], the absorption peak of the complex mixture was a Gaussian linear function and the spectrogram was formed from the superimposed spectral absorption intensity. After Fourier deconvolution, the Gaussian sub-peak fitting was carried out, and the area of each oxygen-containing functional group was calculated accordingly. The Gaussian function used in this study was,

$y=y_{0}+\frac{A}{\omega \sqrt{\pi / 2}} \exp \left[-2 \frac{\left(x-x_{\mathrm{c}}\right)^{2}}{\omega^{2}}\right]$

where $y_{0}$ is baseline, $A$ is the sub-peak area, $\omega$ is full width at half maximum (FWHM) and $x_{\mathrm{c}}$ is the peak position.

Because oxygen-containing groups do not exist independently in coal but instead have intermolecular forces with other groups, the absorbance of coal within a certain wavenumber range could be used to reflect the chemical reaction level of certain types of groups. As shown in Fig. 3, among the 19 peaks in transmission spectrum of coal, the main absorption peak at $3600-3100 \mathrm{~cm}^{-1}$ was caused by the stretching of hydroxyl bond and hydrogen bond-associated hydroxyl, which could be divided into five peaks, and the peak at $3500 \mathrm{~cm}^{-1}$ represented phenol $-\mathrm{OH}$. Peaks at $1800-1550 \mathrm{~cm}^{-1}$ were caused by the stretching vibration $-\mathrm{COOH}$ and aliphatic $\mathrm{C}=\mathrm{O}$, which could be divided into nine peaks. The peak at $1680 \mathrm{~cm}^{-1}$ represented $\mathrm{C}_{\mathrm{al}}=\mathrm{O}\left(\mathrm{C}_{\mathrm{al}}\right.$, aliphatic carbon $)$, and the peak at $1750 \mathrm{~cm}^{-1}$ represented $-\mathrm{COOH}$ [28]. The peak at $1300-1100 \mathrm{~cm}^{-1}$ was caused by the vibration of $\mathrm{C}-\mathrm{O}-\mathrm{C}$, 
Table 2 Area of absorption peak in FTIR spectra

\begin{tabular}{llrrrrr}
\hline $\begin{array}{l}\text { Functional } \\
\text { groups }\end{array}$ & $\begin{array}{l}\text { Center/ } \\
\mathrm{cm}^{-1}\end{array}$ & $\begin{array}{l}\text { Width/ } \\
\mathrm{cm}^{-1}\end{array}$ & \multicolumn{4}{c}{ Area (absorbance unit $\times \mathrm{cm}^{-1}$ ) } \\
\cline { 5 - 7 } & & & $25{ }^{\circ} \mathrm{C}$ & $350^{\circ} \mathrm{C}$ & $450{ }^{\circ} \mathrm{C}$ & $550{ }^{\circ} \mathrm{C}$ \\
\hline$-\mathrm{OH}$ & 3500 & 113 & 24.6 & 24.5 & 23.2 & 22.6 \\
$-\mathrm{C}=\mathrm{O}$ & 1680 & 40 & 7.8 & 7.5 & 0.4 & 0.07 \\
$-\mathrm{COOH}$ & 1750 & 31 & 12.8 & 7.9 & 4.3 & 1.3 \\
$\mathrm{C}-\mathrm{O}-\mathrm{C}$ & 1165 & 34 & 8.6 & 7.9 & 4.6 & 1.3 \\
\hline
\end{tabular}

which could be divided into five peaks. The peak at $1165 \mathrm{~cm}^{-1}$ represented $\mathrm{C}-\mathrm{O}-\mathrm{C}$.

As listed in Table 2, the peak area was taken as the semiquantitative analysis parameter of oxygen-containing groups. Compared with the findings from Xin et al. [15], coal samples contained more oxygen-containing functional groups, and the content of $-\mathrm{OH}$ in coal samples was the highest, which was followed by that of $-\mathrm{COOH}$. The content of $-\mathrm{C}=\mathrm{O}$ and $\mathrm{C}-\mathrm{O}-\mathrm{C}$ was less than that of the former two. To observe the decomposition ratio of oxygen functional groups during the pyrolysis, with the content of each group in the raw coal taken as $100 \%$, the change in the relative decomposition rate of four functional groups is shown in Fig. 4.

According to Fig. 4, chemical bonds of hydroxyl were difficult to break down, and the final decomposition rate was $8.2 \%$ at $550{ }^{\circ} \mathrm{C}$. Within the studied temperature range, the decomposition of carboxyl was fast at first, slowed down in the next stage, and become fast again in the final stage. The final decomposition rate of carboxyl was $90 \%$. The decomposition of carbonyl was fast at $350-450{ }^{\circ} \mathrm{C}$, which can be considered as the main range of pyrolysis temperature, and the final decomposition rate of carbonyl reached $99.2 \%$. The decomposition of the ether group

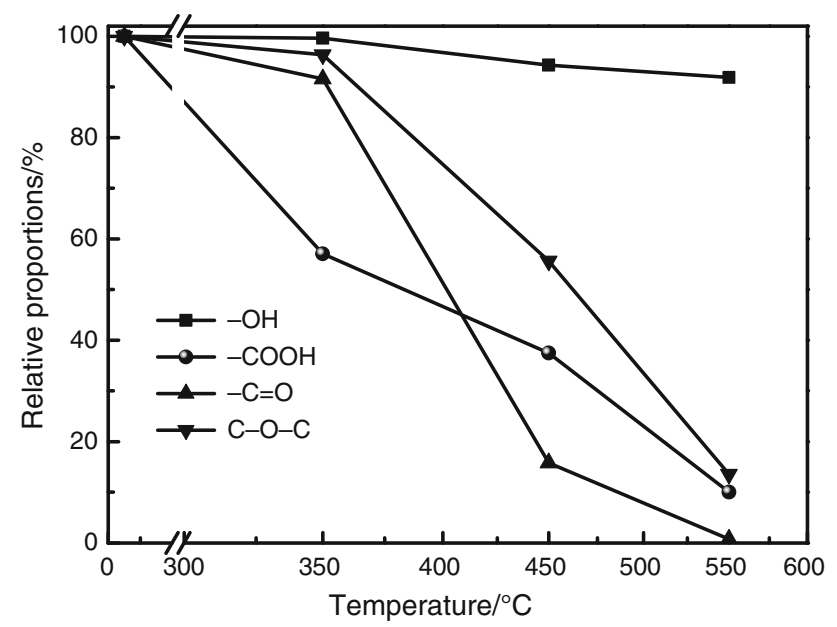

showed a low level of decomposition in the initial stage and decomposed mainly at $350-550{ }^{\circ} \mathrm{C}$. The decomposition rate of the ether group was $86 \%$ at $550{ }^{\circ} \mathrm{C}$ because of the high bond energy of ether.

\section{Oxygen-containing compounds in gas and tar}

The gas was quantitatively analyzed with TIC spectrogram after being separated on GC-MS at $300{ }^{\circ} \mathrm{C}$. The results showed that the oxygen-containing components in gas were mainly $\mathrm{CO}$ and $\mathrm{CO}_{2}$. The tar, from the labile bridge dissociation and decomposition of oxygen-containing macromolecule organics, included phenol, cresol, naphthol, aldehyde and ketones $[29,30]$. Table 3 shows the infrared gas absorption wavenumber in oxygen-containing compounds in the detected volatiles, and Fig. 5 shows the infrared gas absorption spectrogram under continuous temperature rise.

As shown in Fig. 5, the water was completely evaporated before $200{ }^{\circ} \mathrm{C}$, but $\mathrm{H}_{2} \mathrm{O}$ absorption peak still appeared at approximately $450{ }^{\circ} \mathrm{C}$, which was possibly caused by the combination of unstable $-\mathrm{OH}$ and free radical $\mathrm{H}^{+}$[31].

The $-\mathrm{COOH}$ was decomposed into $\mathrm{CO}_{2}$ at $200-250{ }^{\circ} \mathrm{C}$, and more concentrated $\mathrm{CO}_{2}$ was released at approximately $520{ }^{\circ} \mathrm{C}$, which was higher than the $\mathrm{CO}$ releasing temperature at approximately $300-350{ }^{\circ} \mathrm{C}$ [32]. Because the C-S bond in thiophene was relatively stable, COS was released from pyrite in the reduction reaction. When the temperature reached to approximately $550{ }^{\circ} \mathrm{C}$, an epoxy compound with a low wavenumber was formed from free oxygencontaining groups.

As shown in Fig. 6, significant amounts of $\mathrm{CO}$ and $\mathrm{CO}_{2}$ with only a small amount of low molecular weight hydrocarbons could be detected at $350{ }^{\circ} \mathrm{C}$ [32]. At $450{ }^{\circ} \mathrm{C}$, the amount of evoluted gas increased significantly with the residence time. At $550{ }^{\circ} \mathrm{C}$, the amount of evoluted gas decreased significantly. With the increase in temperature,

Table 3 Infrared absorption wavenumber of oxygenated compound

\begin{tabular}{ll}
\hline Oxygenated compound & Wavenumber/cm \\
\hline Water & 3365 \\
Carbon monoxide & 2176 \\
Carbon dioxide & 2360 \\
Carbon oxysulfide & 1341 \\
Phenols & $3650-3500$ \\
Aldehydes and ketones & $1750-1680$ \\
Oxygen heterocycle & $950-810$ \\
\hline
\end{tabular}

Fig. 4 Pyrolysis rate of functional groups 


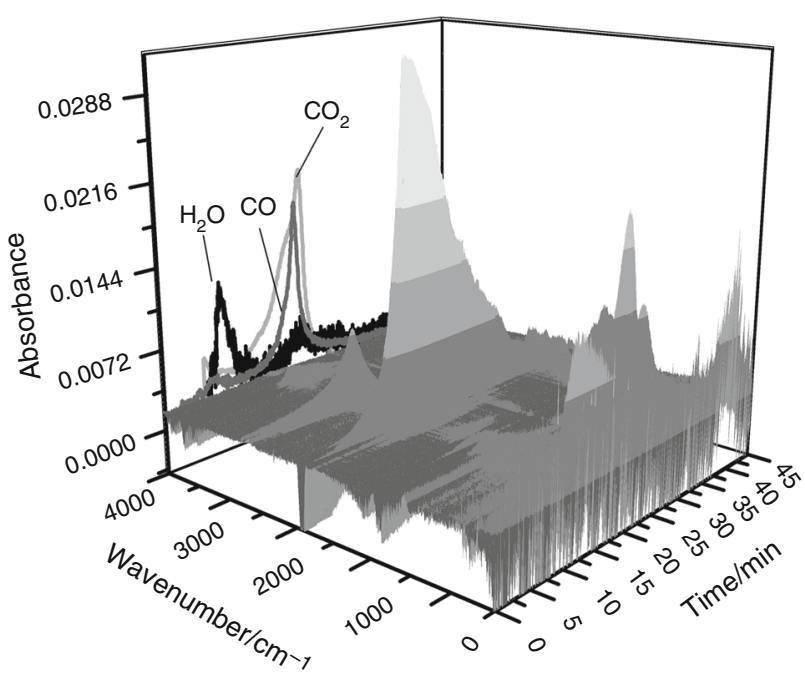

Fig. 5 FTIR spectrum of volatiles

hundreds of oxygen-containing gas molecules were detected, as shown in Table 4.

During the low-temperature pyrolysis, the unstable bridged bond might be decomposed into broken oxygen-containing pieces and radicals, which could further form stable compounds. The decomposition rates of functional groups into different products at 350, 450 and $550{ }^{\circ} \mathrm{C}$ are shown in Table 5. It can be seen that the ratios of $-\mathrm{OH},-\mathrm{COOH},-\mathrm{C}=\mathrm{O}$ and $\mathrm{C}-\mathrm{O}-\mathrm{C}$ were $46,14,25$ and $15 \%$ in all four functional groups, respectively. Figure 4 and Table 5 show that, within the high decomposition temperature at $550{ }^{\circ} \mathrm{C}$, the decomposition rate of $-\mathrm{OH}$ was $8 \%$, in which $0.19 \%$ of unstable $-\mathrm{OH}$ combined with $\mathrm{H}^{+}$to form water. At low temperature, stable $-\mathrm{OH}$ made it difficult to generate water through pyrolysis. Instead, the $-\mathrm{OH}$ mainly migrated to tar in the form of macromolecules, which could be broken into methylphenol [33]. Therefore, the main decomposition sources of oxygen-containing components in tar were oxygen-containing phenyl phenol. Additionally, the migration of hydroxyl oxygen, which was $3.68 \%$ of the total migrated oxygen, occurred.

MacPhee reported that the decomposition of $-\mathrm{COOH}$ generated $\mathrm{CO}_{2}$ [34] and that the hydrogen generated from condensation between free radicals might participate in the formation of benzene [35]. As shown in Fig. 6, the release of $\mathrm{CO}_{2}$ also matched the decomposition of $-\mathrm{COOH}$. Before the temperature reached $350{ }^{\circ} \mathrm{C}, 38.7 \%$ of total $-\mathrm{COOH}$ were decomposed with a decomposition ratio of $28.2 \%$ at $350-450{ }^{\circ} \mathrm{C}$, thus the main decomposition temperature range was $<450{ }^{\circ} \mathrm{C}$. The decomposition ratio was $23.1 \%$ from 450 to $550{ }^{\circ} \mathrm{C}$, which was the secondary decomposition temperature interval. In this condition, $-\mathrm{COOH}$ decomposition rates were consistent with $\mathrm{CO}_{2}$ generation.

At $350{ }^{\circ} \mathrm{C}, 40.1 \%$ of $-\mathrm{C}=\mathrm{O}$ was decomposed into $\mathrm{CO}$ [36]. The infrared transmission results of coal showed that, when the temperature reached $450{ }^{\circ} \mathrm{C}$, up to $94.81 \%$ of $\mathrm{C}=\mathrm{O}$ was decomposed, as shown in Table 5. As shown in Fig. 6a and b, aldehydes and ketones were formed from $\mathrm{C}=\mathrm{O}$ on the free side chain of the molecule and a hydrogen radical. Within the 450 to $550{ }^{\circ} \mathrm{C}$ range, the $\mathrm{CO}$ concentration increased with the increasing temperature, mainly due to the substantial decomposition of $\mathrm{C}-\mathrm{O}-\mathrm{C}$ [37].

The decomposition rate of $\mathrm{C}-\mathrm{O}-\mathrm{C}$ was faster at $450{ }^{\circ} \mathrm{C}$ than it was at $350^{\circ} \mathrm{C}$, with a decomposition ratio of $44.71 \%$, in which the $\mathrm{C}_{\mathrm{al}}-\mathrm{O}$ bond was almost completely decomposed into $\mathrm{CO}$ [38]. Within 450 to $550{ }^{\circ} \mathrm{C}$, the decomposition ratio of coal was $41.3 \%$, in which $38.98 \%$ was turned into $\mathrm{CO}$ with $2.32 \%$ of $\mathrm{C}_{\mathrm{ar}}-\mathrm{O}$ (aromatic carbon-oxygen bond). The difficult-to-decompose $\mathrm{C}_{\mathrm{ar}}-\mathrm{O}$ became an aromatic radical side chain of the macromolecule. The aromatic radical usually bonded to a free $\mathrm{H}^{+}$ at one end of $\mathrm{O}^{2-}$ to form naphthols that were detected in the tar, or bonded to other hydrocarbon radicals to form more stable compounds [38].

The oxygen migration amounts toward gas and tar could be calculated according to Table 4 and loss laws. As shown in Fig. 7, oxygen migration amounts toward gas and tar were 2.3 and $0.007 \%$ at $350{ }^{\circ} \mathrm{C}, 3.13$ and $0.22 \%$ within $350-450{ }^{\circ} \mathrm{C}$, and 1.75 and $0.56 \%$ within $450-550{ }^{\circ} \mathrm{C}$, respectively.

\section{Migration characteristics of oxygen element}

According to the analysis on oxygen in raw coal and the asmade solid, liquid and gas pyrolysis products, the oxygencontaining functional groups in coal included hydroxyl, carboxyl, carbonyl and ether in aliphatic or aromatic structure. Decomposition temperatures of these four functional groups were different in different coals [39]. In Yuzhou long-flame coal, the main decomposition temperatures of hydroxyl, carboxyl, carbonyl and ether were $450-550,200-350,350-450$ and $350-450{ }^{\circ} \mathrm{C}$, respectively. The decomposition of carboxyl and carbonyl generated $\mathrm{CO}_{2}$ and $\mathrm{CO}$, respectively. The $\mathrm{H}^{+}$, generated from carboxyl decomposition, form $\mathrm{H}_{2} \mathrm{O}$ with free hydroxyl radical. The carbonyl could also transform into aldehydes and ketones through cyclization. Most of the ether bond was decomposed into $\mathrm{CO}$ with small amounts decomposing into furan and naphthol through cyclization [38]. Hydroxyl was mainly distributed as functional groups in tar.

During the pyrolysis, the migration of elemental oxygen indicated the impossibility of oxygen removal in the simple form of $\mathrm{O}_{2}$, but its easy removal in the form of oxygencontaining compounds in the products gas and tar. In gas, the main forms of oxygen were $\mathrm{CO}$ and $\mathrm{CO}_{2}$ without the $\mathrm{H}^{+}$carried along. In tar, oxygen bonded with carbon and hydrogen to form oxygen-containing compounds. The relative amount of elemental oxygen was taken as $100 \%$, and 
Fig. 6 Gas chromatography of gas products collected at different temperatures. a $350{ }^{\circ} \mathrm{C}$. b $450{ }^{\circ} \mathrm{C}$. c $550{ }^{\circ} \mathrm{C}$

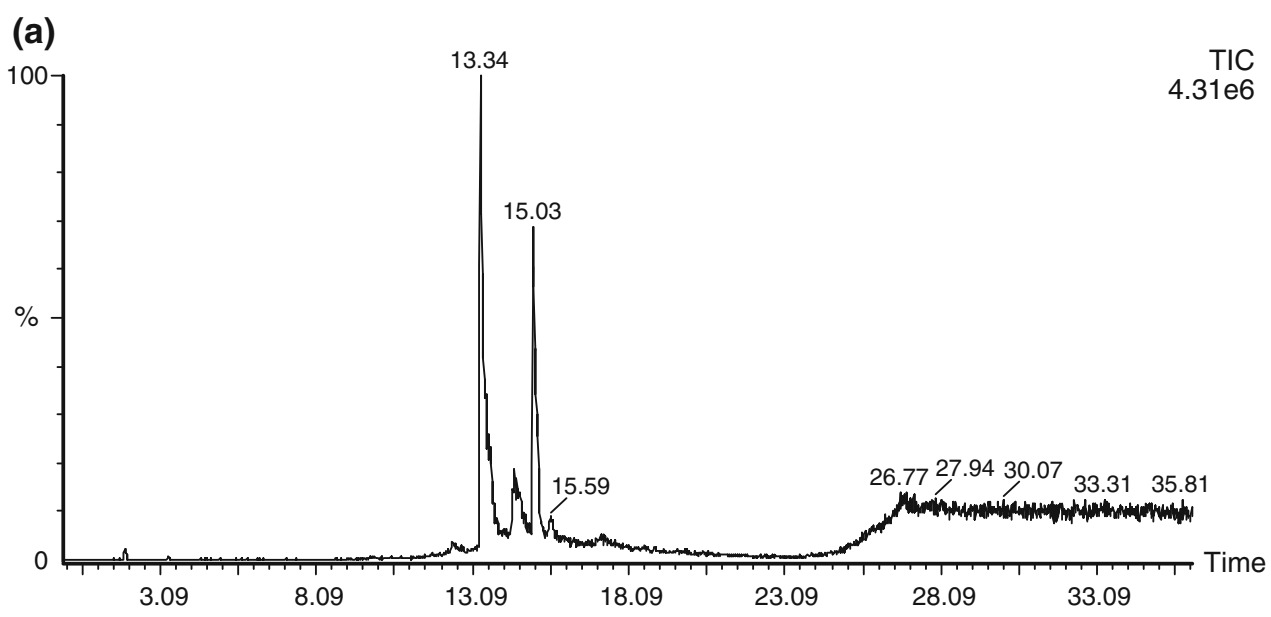

(b)
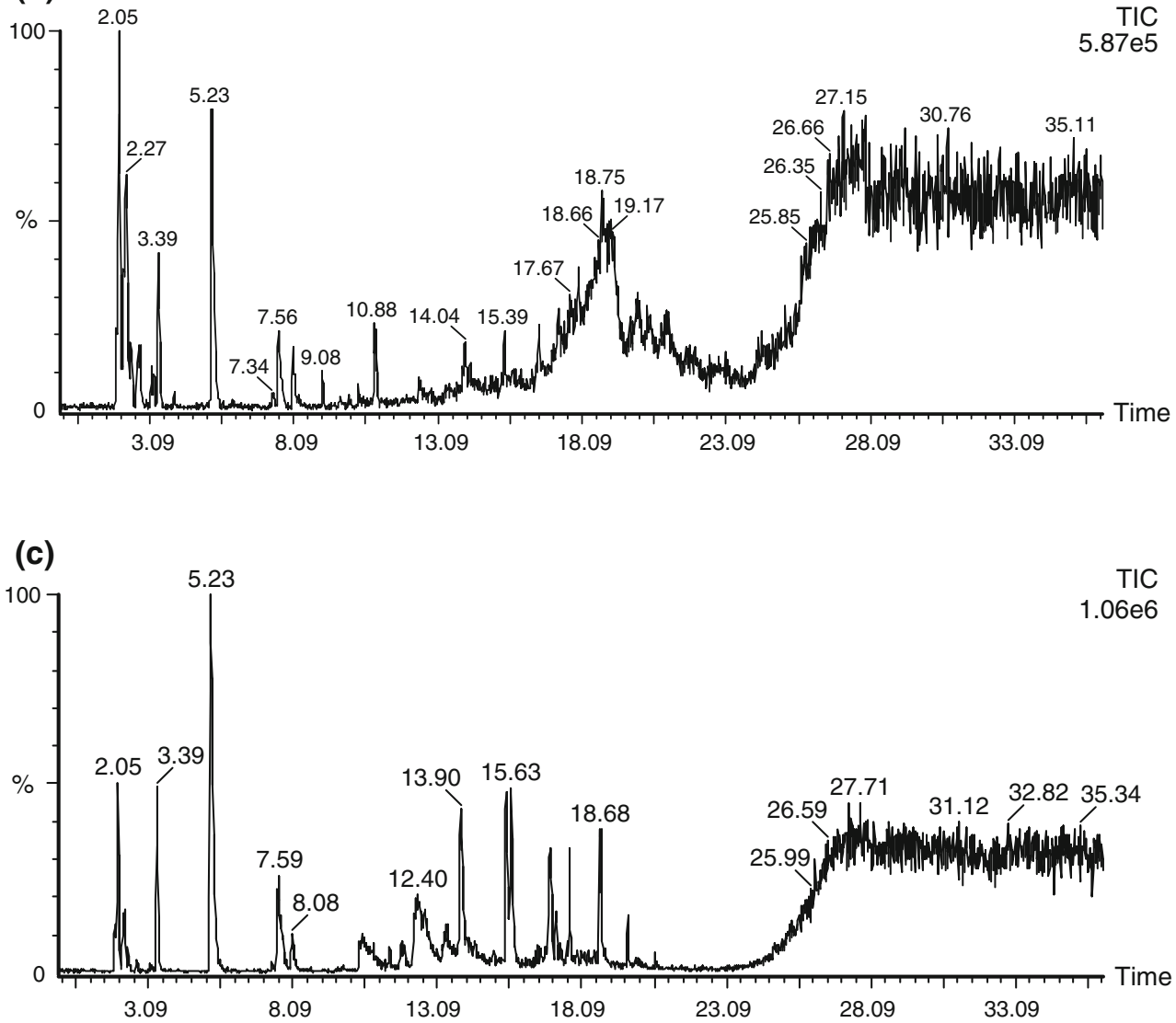

the ratio of oxygen over carbon and hydrogen in the product was used as the indicator of the migration ratio.

As listed in Table 6, the ratio of carbon in the semi-coke gradually increased with the increase in temperature, indicating a gradual decrease in oxygen-bonded carbon. The ratio of hydrogen decreased at $350{ }^{\circ} \mathrm{C}$, which might be caused by the formation of hydrocarbon volatiles. From 450 to $550{ }^{\circ} \mathrm{C}$, the ratio of hydrogen increased due to the substantial decomposition of low-hydrogen oxygen- containing functional groups, and $\mathrm{O} / \mathrm{H}$ gradually approached 1:1 in hydroxyl. In gas, the value of $\mathrm{O} / \mathrm{C}$ had its highest point as the temperature was increased to $450{ }^{\circ} \mathrm{C}$. When the temperature was increased, oxygen-containing compounds in tar gradually increased along with the increase in their molecular weights. Because most of these oxygen-containing compounds only had one oxygen element, the increased ratio of carbon and hydrogen indicated that high-quality tar was obtained. As shown in Table 4, in 
Table 4 Oxygen-containing compounds relative peak area

\begin{tabular}{|c|c|c|c|c|c|}
\hline \multirow[t]{2}{*}{ No. } & \multirow[t]{2}{*}{ Compounds } & \multirow[t]{2}{*}{ Formula } & \multicolumn{3}{|c|}{ Relative peak area/\% } \\
\hline & & & $350{ }^{\circ} \mathrm{C}$ & $450{ }^{\circ} \mathrm{C}$ & $550^{\circ} \mathrm{C}$ \\
\hline 1 & Water & $\mathrm{H}_{2} \mathrm{O}$ & - & 0.1 & 0.2 \\
\hline 2 & Carbon monoxide & $\mathrm{CO}$ & 25.6 & 32.5 & 28.6 \\
\hline 3 & Carbon dioxide & $\mathrm{CO}_{2}$ & 48.2 & 35.1 & 28.8 \\
\hline 4 & Carbon oxysulfide & COS & - & 0.2 & 0.2 \\
\hline 5 & Furan & $\mathrm{C}_{4} \mathrm{H}_{4} \mathrm{O}$ & 0.2 & 0.4 & 0.1 \\
\hline 6 & Cyclopentanone & $\mathrm{C}_{5} \mathrm{H}_{8} \mathrm{O}$ & - & 1.5 & 2.4 \\
\hline 7 & Phenol & $\mathrm{C}_{6} \mathrm{H}_{6} \mathrm{O}$ & - & 0.5 & 3.5 \\
\hline 8 & Cresol & $\mathrm{C}_{7} \mathrm{H}_{8} \mathrm{O}$ & - & 2.6 & 5 \\
\hline 9 & Dimethyl phenol & $\mathrm{C}_{8} \mathrm{H}_{10} \mathrm{O}$ & - & - & 0.2 \\
\hline 10 & $\begin{array}{l}\text { Phenylpropyl } \\
\text { aldehyde }\end{array}$ & $\mathrm{C}_{9} \mathrm{H}_{10} \mathrm{O}$ & - & 0.3 & 0.3 \\
\hline 11 & Naphthol & $\mathrm{C}_{10} \mathrm{H}_{8} \mathrm{O}$ & - & - & 0.6 \\
\hline 12 & Hydroxyquinoline & $\mathrm{C}_{9} \mathrm{H}_{7} \mathrm{NO}$ & - & 0.2 & 1.2 \\
\hline 13 & $\begin{array}{l}\text { 3-Ethyl amino-4- } \\
\text { cresol }\end{array}$ & $\mathrm{C}_{9} \mathrm{H}_{13} \mathrm{NO}$ & - & - & 0.3 \\
\hline 14 & Methoxynaphthol & $\mathrm{C}_{11} \mathrm{H}_{10} \mathrm{O}_{2}$ & - & 0.1 & 0.1 \\
\hline 15 & 13 alcohols & $\mathrm{C}_{13} \mathrm{H}_{28} \mathrm{O}$ & - & - & 0.1 \\
\hline
\end{tabular}

these as-obtained oxygen-containing compounds, the gas played a decisive role in the oxygen migration, and $550{ }^{\circ} \mathrm{C}$ was an ideal and reasonable temperature to obtain a low oxygen migration level.

\section{Discussion of character changes of long-flame coal}

Oxygen has a significant effect on the hydrophilicity of coal. Temperature is the most effective parameter on changing the hydrophilicity with a sharp change in oxygencontaining function groups and specific surface area [40]. As shown in Fig. 8, the semi-cokes collected at different pyrolysis temperatures absorbed water after a long time in

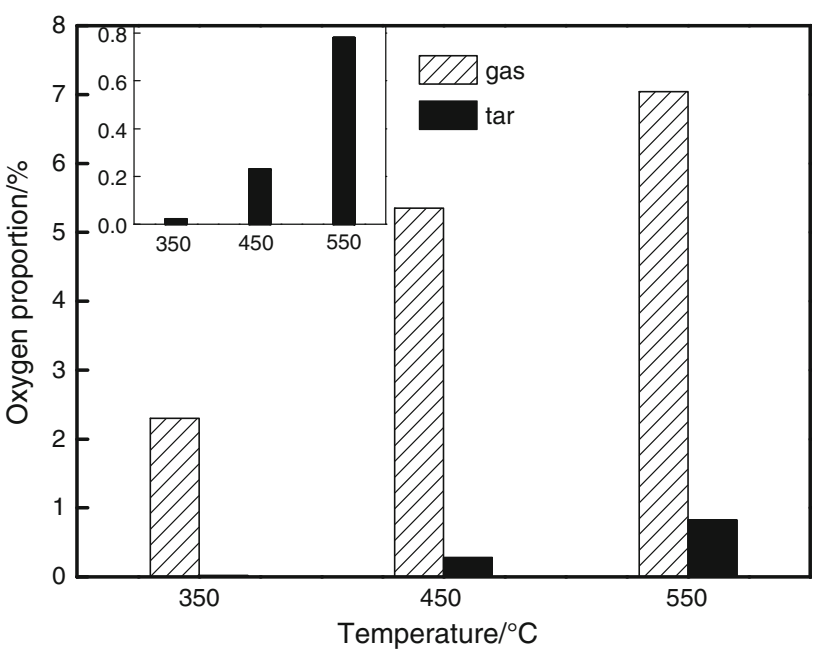

Fig. 7 Oxygen proportion in gas and tar

Table $6 \mathrm{O} / \mathrm{C} / \mathrm{H}$ value in pyrolysis products

\begin{tabular}{llll}
\hline Temperature $/{ }^{\circ} \mathrm{C}$ & Solid & Gas & Coal-oil \\
\hline 25 & $1: 5.11: 0.45$ & - & - \\
350 & $1: 6.32: 0.42$ & $1: 0.61: 0$ & $1: 4: 4$ \\
450 & $1: 9: 0.55$ & $1: 0.66: 0$ & $1: 6.30: 7.51$ \\
550 & $1: 12.81: 0.76$ & $1: 0.62: 0$ & $1: 6.81: 7.66$ \\
\hline
\end{tabular}

the air because of their oxygen-containing function groups and specific surface area. According to [41], although the pore structures of semi-cokes collected at different pyrolysis temperatures were almost the same, the water content of the coal decreased with an increase in temperature because the carboxyl in the coal was better to hold water than phenolic hydroxyl.

As shown in Fig. 8, the high-oxygen content led to high water production during the coal liquefaction. Theoretically, the efficiency of liquefaction increases with increasing $\mathrm{H} / \mathrm{C}$ ratio and with decreasing $\mathrm{O} / \mathrm{C}$ ratio, and the

Table 5 The decomposition rates of functional groups into different products at 350,450 and $550{ }^{\circ} \mathrm{C}$

\begin{tabular}{|c|c|c|c|c|c|}
\hline \multirow[t]{2}{*}{ Functional groups } & \multirow{2}{*}{$\begin{array}{l}\text { Content of functional } \\
\text { groups in raw coal } / \%\end{array}$} & \multirow[t]{2}{*}{ Decomposition products } & \multicolumn{3}{|c|}{ Decomposition temperature/\% } \\
\hline & & & $350{ }^{\circ} \mathrm{C}$ & $450{ }^{\circ} \mathrm{C}$ & $550^{\circ} \mathrm{C}$ \\
\hline \multirow[t]{2}{*}{$-\mathrm{OH}$} & \multirow[t]{2}{*}{46} & $\mathrm{H}_{2} \mathrm{O}$ (gas) & 0 & 0.06 & 0.19 \\
\hline & & Phenolic compounds (tar) & 0 & 1.95 & 7.81 \\
\hline$-\mathrm{COOH}$ & 14 & $\mathrm{CO}_{2}$ (gas) & 38.7 & 66.9 & 90 \\
\hline \multirow[t]{2}{*}{$-\mathrm{C}=\mathrm{O}$} & \multirow[t]{2}{*}{25} & $\mathrm{CO}$ (gas) & 40.1 & 50.9 & 91 \\
\hline & & Aldehyde compounds (tar) & 0.31 & 3.81 & 8.21 \\
\hline \multirow[t]{2}{*}{$\mathrm{C}-\mathrm{O}-\mathrm{C}$} & \multirow[t]{2}{*}{15} & $\mathrm{CO}$ (gas) & 0 & 44.3 & 83.28 \\
\hline & & Naphthol compounds (tar) & 0 & 0.41 & 2.73 \\
\hline Total & 100 & - & - & - & - \\
\hline
\end{tabular}




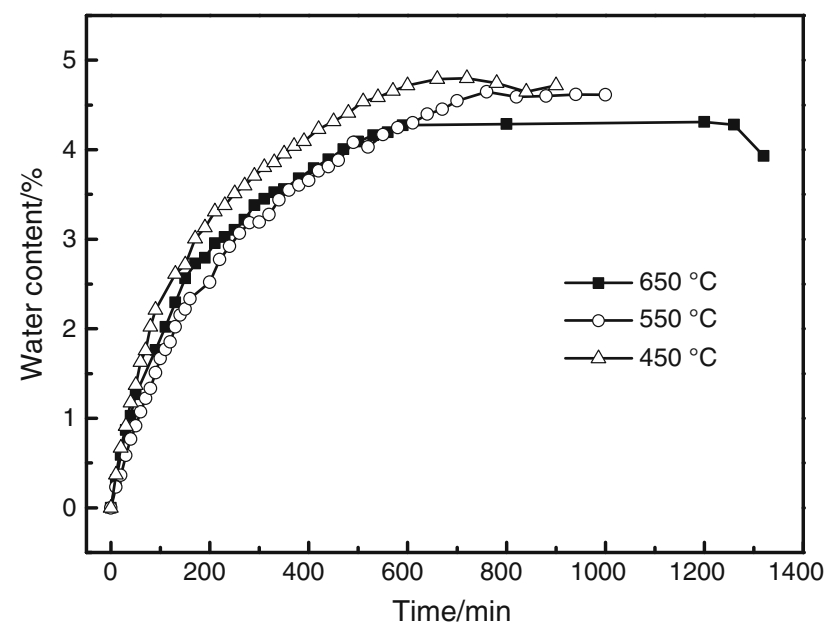

Fig. 8 Water content of semi-coke

efficiency of gasification decreases with decreasing O/C ratio, but $\mathrm{H} / \mathrm{C}$ decreases with decreasing $\mathrm{O} / \mathrm{C}$ ratio in this study, which can be inferred from Table 6; the $\mathrm{H} / \mathrm{C}$ ratio was reduced from 0.09 to 0.06 , and the $\mathrm{O} / \mathrm{C}$ ratio was reduced from 0.20 to 0.08 , which indicated that the $\mathrm{O} / \mathrm{C}$ ratio decreased more than the $\mathrm{H} / \mathrm{C}$ ratio. Therefore, the semi-coke might be a better raw material for liquefaction than the long-flame coal.

\section{Conclusions}

In this study, the migration behavior of oxygen and the variation of Chinese long-flame coal properties during lowtemperature pyrolysis were carried out using TG-FTIRGC/MS methods. The main conclusions obtained are as follows:

1. Low-temperature pyrolysis is an efficient way for deoxygenation of Yuzhou long-flame coal. Migration ratios of oxygen to gas at 350 and $450{ }^{\circ} \mathrm{C}$ were 15.4 and $36.2 \%$, that to tar was $1.48 \%$ at $450{ }^{\circ} \mathrm{C}$. At $550{ }^{\circ} \mathrm{C}$, migration ratios of oxygen to gas and tar were 47.7 and $5.2 \%$, respectively. Further research is still necessary to reduce oxygen retention rate in the solid product.

2. Analyze of oxygen migration in oxygen-containing functional groups in different temperature gives a clear view on the fate of oxygen during deoxygenation process. At 350,450 and $550{ }^{\circ} \mathrm{C}$, the migration ratios of $-\mathrm{COOH}$ oxygen, mainly $\mathrm{CO}_{2}$, were $9.7,16.7$ and $22.5 \%$, respectively; the migration ratios of $\mathrm{C}=\mathrm{O}$ oxygen were 5.7, 13.3 and $13.9 \%$ (12.76\% into $\mathrm{CO}$ gas and $1.14 \%$ into aldehyde within the tar); the migration ratios of $\mathrm{C}-\mathrm{O}$ oxygen were $0,6.7$ and $12.9 \%$ (12.5\% into $\mathrm{CO}$ gas and $0.4 \%$ into phenolic compounds in tar); $-\mathrm{OH}$ oxygen migrated only at $550{ }^{\circ} \mathrm{C}$ into mainly phenolic compounds with a migration ratio of $3.7 \%$. All the oxygen-containing functional groups, in which $-\mathrm{OH}$ is the main trouble result in oxygen retention in solid product.

3. The $\mathrm{O} / \mathrm{C} / \mathrm{H}$ was obtained in different pyrolysis products. The $\mathrm{O} / \mathrm{C} / \mathrm{H}$ of semi-coke, gas and tar were 1:6.32:0.42, 1:0.61:0 and 1:4:4: at $350{ }^{\circ} \mathrm{C}, 1: 9: 0.55$, $1: 0.66: 0$ and $1: 6.30: 7.51$ at $450{ }^{\circ} \mathrm{C}, 1: 12.81: 0.76$, 1:0.62:0 and $1: 6.81: 7.66$ at $550{ }^{\circ} \mathrm{C}$, respectively, which suggested that low oxygen migration ratio and improved ratio of carbon and hydrogen in coal could be obtained at a low temperature. Additionally, deoxygenation could reduce the hydrophilicity of long-flame coal significantly and might improve its possibility of liquefaction.

Acknowledgements Financial support by from the National Key R\&D Program (Project No. 2016YFB0601501) is gratefully acknowledged. The authors also thank for the suggestion of Dr. Sen Li on this work.

\section{References}

1. Nurhadi M, Efendi J, Lee SL, Mahlia TMI, Chandren S, Ho CS, Nur H. Utilization of low rank coal as oxidation catalyst by controllable removal of its carbonaceous component. J Taiwan Inst Chem E. 2015;46:183-90.

2. Rao ZH, Zhao YM, Huang CL, Duan CL, He JF. Recent developments in drying and dewatering for low rank coals. Prog Energy Combust Sci. 2015;46:1-11.

3. Ju YS, Lee CH. Evaluation of the energy efficiency of the shell coal gasification process by coal type. Energy Convers Manage. 2017;143:123-36.

4. Deng J, Zhao JY, Xiao Y, Zhang YN, Huang AC, Shu CM. Thermal analysis of the pyrolysis and oxidation behaviour of $1 / 3$ coking coal. J Therm Anal Calorim. 2017; doi:10.1007/s10973017-6331-3.

5. Soncini RM, Means NC, Weiland NT. Co-pyrolysis of low rank coals and biomass: product distributions. Fuel. 2013;112(3):74-82.

6. Trautmann M, Lang S, Traa Y. Direct liquefaction of lower-rank coals and biocoals with magnetically separable catalysts as a sustainable route to fuels. Fuel. 2015;151:102-9.

7. Wang JF, Yan QX, Zhao JT, Wang ZQ, Huang JJ, Gao SP, Song SS, Fang YT. Fast co-pyrolysis of coal and biomass in a fluidized-bed reactor. J Therm Anal Calorim. 2014;118:1663-73.

8. Rizkiana J, Guan GQ, Widayatno WB, Hao XG, Huang W, Tsutsumid A, Abudula A. Effect of biomass type on the performance of cogasification of low rank coal with biomass at relatively low temperatures. Fuel. 2014;134(9):414-9.

9. Dlouhý T, editor. Low-rank coal properties, upgrading and utilization for improving fuel flexibility of advanced power plants. In Advanced power plant materials, design and technology. 2010. p. 291-311.

10. Cormos CC, Starr F, Tzimas E. Use of lower grade coals in IGCC plants with carbon capture for the co-production of hydrogen and electricity. Int J Hydrogen Energy. 2010;35(2):556-67.

11. Tsubouchi N. Effects of solid residence time and inherent metal cations on the fate of the nitrogen in coal during rapid pyrolysis. Energy Fuels. 2014;28(9):5721-8. 
12. Qu X, Liang P, Zhang R, Gan ZX, Bi JC. Sulfur transformation in the process of circulating fluidized bed combustion combined with coal pyrolysis. Energy Fuels. 2010;24(9):5023-7.

13. Borislav GA, Manovic V. Influence of non-uniformity of coal and distribution of active calcium on sulfur self-retention by ash-A case study of lignite kolubara. Energy Fuels. 2002;16(4):951-5.

14. Solomon PR, Hamblen DG, Carangelo RM. Applications of Fourier transform IR spectroscopy in fuel science, coal and coal products. In Fuller EL, editor. Analytical characterization techniques. ACS symposium series 205, Washington; 1982. p. 77.

15. Xin HH, Wang DM, Qi XY, Qi GS, Dou GL. Structural characteristics of coal functional groups using quantum chemistry for quantification of infrared spectra. Fuel Process Technol. 2014;118(2):287-95.

16. Lievens C, Ci DH, Bai Y, Ma LG, Zhang R, Chen JY, Gai QQ, Long $\mathrm{YH}$, Guo XF. A study of slow pyrolysis of one low rank coal via pyrolysis-GC/MS. Fuel Process Technol. 2013;116(4):85-93.

17. Lin YK, Li QS, Li XF, Ji K, Zhang HP, Yu YM, Song YH, Fu Y, Sun LY. Pyrolysares distribution and kinetics of Shenmu long flame coal. Energ Convers Manage. 2014;86:428-34.

18. Liu HH, Mou JH, Cheng YP. Impact of pore structure on gas adsorption and diffusion dynamics for long-flame coal. J Nat Gas Sci Eng. 2015;22:203-13.

19. Ma L, Lu D, Liang HD, Zhu SQ, Ding Y, Li S, Chen YF. Preliminary study on macromolecular structure characteristics of Shenhua long flame coal. J Fuel Chem Technol. 2013;41(5):513-22.

20. Xu Y, Zhang YF, Zhang GJ, Guo YF, Zhang J, Li GQ. Pyrolysis characteristics and kinetics of two Chinese low-rank coals. J Therm Anal Calorim. 2015;122:975-84.

21. Cui X, Li XL, Li YM, Li S. Evolution mechanism of oxygen functional groups during pyrolysis of Datong coal. J Therm Anal Calorim. 2017;129(2):1169-80.

22. Dong PW, Chen G, Zeng X, Chu M, Gao SQ, Xu GW. Evolution of inherent oxygen in solid fuels during pyrolysis. Energy Fuels. 2015;29(5):2268-76.

23. Zhao P, Shi SD. Study on the release of oxygen functional group in Shengli lignite during preliquefaction. J China Coal Soc. 2009;2(3):44-7.

24. Mráziková J, Sindler S, Veverka LS, Mack JR. Evolution of organic oxygen bonds during pyrolysis of coal. Fuel. 1986;65(3):342-5.

25. Sharma RK, Wooten JB, Baliga VL, Hajaligol MR. Characterization of chars from biomass-derived materials: pectin chars. Fuel. 2001;80(12):1825-36.

26. Sharma RK, Wooten JB, Baliga VL, Lin XH, Chan WG, Hajaligol MR. Characterization of chars from pyrolysis of lignin. Fuel. 2004;83(11-12):1469-82.
27. Geng WH, Nakajima T, Takanashi H, Ohki A. Analysis of carboxyl group in coal and coal aromaticity by Fourier transform infrared (FT-IR) spectrometry. Fuel. 2009;88(1):139-44.

28. Wang SQ, Tang YG, Harold HS, Guo YN, Gao WC, Lu XK. FTIR and simultaneous TG/MS/FTIR study of late permian coals from southern China. J Anal Appl Pyrol. 2013;100:75-80.

29. He QQ, Wan KJ, Hoadley A, Yeasmin H, Miao ZY. TG-GC-MS study of volatile products from Shengli lignite pyrolysis. Fuel. 2015;156:121-8.

30. Charlanda JP, MacPheea JA, Girouxa L, Pricea JT, Khanb MA. Application of TG-FTIR to the determination of oxygen content of coals. Fuel Process Technol. 2003;81(3):211-21.

31. Liu JX, Jiang XM, Shen J, Zhang H. Pyrolysis of superfine pulverized coal. Part 1. Mechanisms of methane formation. Energy Convers Manage. 2014;87:1027-38.

32. Tian LN, Yang W, Chen ZH, Wang XH, Yang HP, Chen HP. Sulfur behavior during coal combustion in oxy-fuel circulating fluidized bed condition by using TG-FTIR. J Energy Inst. 2016;89:264-70.

33. Yan L, Bai Y, Zhao R, Fan L, Xie K. Correlation between coal structure and release of the two organic compounds during pyrolysis. Fuel. 2015;145(145):12-7.

34. MacPhee JA, Charland JP, Giroux L. Application of TG-FTIR to the determination of oxygen content of coals. Fuel Process Technol. 2006;87(4):335-41.

35. Artok L, Schobert HH. Reaction of carboxylic acids under coal liquefaction conditions 1 . Under nitrogen atmosphere. J Anal Appl Pyrol. 2000;54(1-2):215-33.

36. Wang HH, Dlugogorski BZ, Kennedy EM. Thermal decomposition of solid oxygenated complexes formed by coal oxidation at low temperatures. Fuel. 2002;81(15):1913-23.

37. Scaccia S. TG-FTIR and kinetics of devolatilization of Sulcis coal. J Anal Appl Pyrol. 2013;104:95-102.

38. Fan N, Meng T, Zhang QM. Pyrolysis of low-rank coal: from research to practice. Pyrolysis. InTech; 2017;14:319-39.

39. Alessio D, Raspolligalletti A, Licursi AM, Martinelli DM. FTIR investigation of the structural changes of Sulcis and south Africa coals under progressive heating in vacuum: correlation with volatile matter. J Combust. 2013;11:1-14.

40. Huang X, Zhang S, Lin XC, Wang YG, Xu M. Deoxygenation effect on hydrophilicity changes of Shengli lignite during pressurized pyrolysis at low temperature. J Fuel Chem Technol. 2013;41(12):1409-14.

41. Yang LJ, Ouyang YL, Ke WL, You Y, Li QH. Research on the impact factors of coal wettability. Coal. 2012;21(8):4-5. 